\title{
Role of Corporate Branding, Customer Involvement and Customer Relationship Proneness in Luxury Fashion Branding
}

(Peranan Penjenamaan Korporat, Hubungan Pelanggan, dan Penglibatan Pelanggan dalam Barang Berjenama Mahal)

\author{
Muhammad Amin \\ Zulkipli Ghazali \\ (Department of Management and Humanities, Universiti Teknologi PETRONAS) \\ Amir Gulzar \\ (Management sciences, Foundation University, Islamabad)
}

\begin{abstract}
The main purpose of the current research is to develop and test a theoretical framework that captures the role of corporate branding (corporate association, symbolic benefits, and functional benefits), customer involvement and customer relationship proneness on customers emotional attachment and brand loyalty in the luxury fashion industry. The nature of this study is quantitative, cross-sectional and non-contrived. This study used a convenient sampling technique for the collection of data. Data were gathered from 315 customers who used to buy luxury fashion brands. This study has adopted a causal analytical approach by which hypotheses were developed and tested. For data analysis, correlation, regression, and descriptive statistics tests were carried out with the help of SPSS and mediation analysis was carried through AMOS. Findings approved that corporate association; symbolic benefits have limited impact on brand loyalty while functional benefits customer involvement and customer relationship proneness have a significant impact on brand loyalty. Findings suggest that emotional attachment fully mediates the relationship of corporate association, symbolic benefits, customer involvement, and brand loyalty, while emotional attachment partially mediates the relationship of functional benefits, customer relationship proneness, and brand loyalty.
\end{abstract}

Keywords: Corporate branding; customer involvement; customer relationship proneness; brand loyalty; emotional attachment

\section{ABSTRAK}

Tujuan utama kajian ini adalah untuk membuat kajian terhadap rangka kerja teori yang menjelaskan peranan penjenamaan korporat (persatuan korporat, faedah simbolik, dan manfaat fungsi), penglibatan pelanggan dan hubungan kecenderungan pelanggan terhadap lampiran emosi pelanggan dan kesetiaan jenama dalam industri fesyen mewah. Kajian ini adalah berbentuk kualitatif, kajian rentas dan mengunakan sampel yang tulus. Kajian ini mengunakan teknik persampelan secara kebetulan untuk mengumpul data. Data telah dikumpul dari 315 pelanggan yang biasanya membeli pakaian berjenama mewah. Kajian ini menggunakan pendekatan analisis hubungan sebab akibat dengan hipótesis mana yang akan dibangunkan dan diuji. Untuk analisis data, korelasi, regresi dan ujian statistik deskriptif telah dijalankan dengan mengunakan aplikasi SPSS dan analisis pengantaraan dijalankan menggunakan AMOS. Penemuan telah membuktikan persatuan korporat; faedah simbolik mempunyai kesan terhad terhadap kesetiaan jenama manakala manfaat penglibatan pelanggan dan hubungan kecenderungan terhadap pelanggan mempunyai impak yang ketara terhadap kesetiaan jenama. Kajian juga mencadangkan bahawa keterikatan emosi memainkan satu fungsi yang menjadi pengantara penuh untuk persatuan korporat, faedah simbolik, penglibatan pelanggan, dan kesetiaan terhadap satu jenama, manakala keterikatan emosi pula menjadi pengantara separa kepada hubungan manfaat fungsi, hubungan kecenderungan pelanggan dan kesetiaan jenama.

Kata kunci: Penjenamaan korporat; penglibatan pelanggan; kesetiaan perhubungan pelanggan; kesetiaan jenama; lampiran emosi

\section{INTRODUCTION}

Luxury fashion branding (LFB) is a concept for those individuals who have prestige state of the art ambiance for a chosen brand. The concept of luxury branding is huge across the industrial categorization of the luxury fashion industry (Esmaeilpour 2015), but previous researchers had found numerous evidence for low benefits from luxury 
fashion branding (Chevalier \& Mazzalovo 2008). However, companies are offering different innovative platforms to their potential customers for the enhancement of their involvement towards companies luxury's fashion brands (Ryan 2009). These innovative platforms are unique in their stylish outlook that create the emotional link between customers and luxury fashion brands (Chevalier \& Mazzalovo 2008). However, what are the values that companies offer through these platforms to their customer to create their emotional bonding with the brands need to be studied (Ko \& Megehee 2012).

Typically, previous studies have been focused on non-luxury sectors like food (Ngobo 2011), while few have investigated the teen agers attitude towards non-luxury brands (Park-Poaps \& Kang 2018). Secondly, past studies have investigated customers purchase intentions towards the LFB from social perspective (Eom \& Seock 2017) and customers buying behaviour towards LFB (Arora 2017). Similarly, studies have also investigated role of communication tactics to attract the customers. Overall, previous researches have contributed more in LFB from management side (Theng So, Grant Parsons \& Yap 2013), but scientific inquiry on the values that emotionally capture the customers towards the brand loyalty $(\mathrm{BL})$ is missing.

$\mathrm{BL}$ is a result of effective corporate branding $(\mathrm{CB})$, their involvement and relationship with brand. These values help them to emotionally attach with LFB and ultimately loyal with the brands. The execution of strong corporate branding strategy provides luxury firms an opportunity to establish unique brands for customers. Conclusively, strong CB strategy can attract customers emotionally with the respective brands and ultimately emotional attachment can command a higher, and sustainable level of loyalty (Theng So et al. 2013). Similarly, Kinley, Josiam and Lockett (2010) affirmed that the high intensity of customer involvement (CI) shows that customer is more committed with the brand for a longer time period. Consumers no more purchase products, they express who they are and identify the relationships that are essential to them through consumption (O'Cass \& Ngo 2011). Overall, facilitation of these values through innovative platforms to the customers can help the companies to attract them emotionally, towards the brand loyalty.

Therefore, the aim of this research is to understand the role of corporate branding, customer involvement and customer relationship proneness (CRP) to attach the customers emotionally towards and behaviourally brand loyal to luxury fashion brands. This paper contributes theoretically and practically to consumer research of LFB. Theoretically this paper develops a framework that undertake the impact of corporate branding, customer involvement and customer relationship proneness on customers emotional attachment and brand loyalty. These values are facilitated by the companies to customers through different innovative platform. The proposed model has multiple advantage, firstly, this model introduces corporate branding, customer involvement and relationship as the value of the customers. Secondly, effect of these values on customers emotional attachment and brand loyalty has not been explored in past studies. From managerial perspective, this research provides strategic importance of values like corporate branding, customer involvement and customers relationship to compete in volatile markets. By knowing the strategic importance of these values managers can understand which value is more important from customers perspective and accordingly firms can invest in them. Overall, this research assists LFB managers to understand the mechanism the underlies the operation of an effective CB, CI and CRP.

\section{REVIEW OF LITERATURE AND HYPOTHESES DEVELOPMENT}

\section{CORPORATE BRANDING}

As evidenced by the literature of Sallam (2016) that, corporate branding is a potential base for organizations to improve their unique features through extensive interactions that establish sound grounds for the firms to grow. Corporate branding is a strategic indicator that can be known as a complete branding management style implemented by organizations to develop CI (Abratt \& Kleyn 2012). The idea of CB has got acceptance in the existing body of knowledge of marketing as $\mathrm{CB}$ is believed to enhance value for the firms offering presented through the firm (Harris \& De Chernatony 2001). The distinctive brand provides obscure value that is unique for the competitor and is distinctive to be copied and replicated, which provide a firm sustainable competitive edge that helps to establish BL (Jo Hatch \& Schultz 2003; Yu Xie \& Boggs 2006). Souiden, Kassim, and Hong (2006) enhanced the body of knowledge proposing specific behavioural components of corporate branding that includes an image, loyalty, reputation, and corporate name which must be considered as an important indicator that contributes as advancements towards corporate branding which further results in the advancement of an LB. Corporate Identity can be achieved through constant control, suitable investment policy from the topmost executive levels (Fionda \& Moore 2009).

Luxury brands are a great source of intangible benefits for customers, these benefits can be through logo or symbol. Luxury brands portray the personality and the values of the company, which brings up a favourable brand association and successful brand image among customers (Okonkwo 2007). Through this intrinsic and extrinsic values, luxury brands charge possible to get a premium price from the customers for their products. Manufacturing and distribution of luxury products are always close attention of the top management. Companies controlled and being highly selective to limit luxury product accessibility to customers (Fionda \& Moore 2009). 
What customer seek during past interaction with the brand, knowledge stored in the customers' memory, which helps the customer to evaluate the brand, it's been referred as customer association (Romaniuk \& Gaillard 2007). CA incorporates feelings, beliefs, and attitude toward a firm, increased by immediate knowledge; information about firm's previous conduct; and summary findings of the firm and its items (Brown \& Dacin 1997). To enhance the loyalty among the chosen target audience it is compulsory for the brand to maintain a strong relationship with their customers. This relationship as evidenced in the above-mentioned literature must be drawn on the effective state to enhance the feelings of chosen customers. Moreover, the case of luxury branding is solely dependent on the type of bond they maintain with their customers and corporate association significantly creates an impact to enhance loyalty among the chosen target audience. Based on the above-developed argument, the research study can formulate certain role of corporate association that direct us to conclude that corporate association is developed only when business came across a various set of contexts in order to enhance an understanding of a various set of actions, ii. CA is an important factor that drives behaviour and uplift and provokes positive sentimental associations in orienting behaviours specifically when the context is complex to allow various explanations in a mutual situation of marketing or any future-oriented valuation is desired. Moreover as discussed in the aforementioned argument that corporate association is keen to meld certain behaviours and interface for different behaviours have been highlighted as critical factors towards the formulation of corporate association (La Rocca 2011).

Brand loyalty is an important consideration for brand equity. Beneke and Zimmerman (2014) again evidenced as an affection of brand in the mind of the customer (Tran, Dauchez, \& Szemik 2013). Furthermore, this factor is considered to be an important contribution because even in prices of any brand are raising the customer shall never feel hesitated to pay nor he or she will switch their priorities to any other brand (Reisenwitz \& Gupta 2011). A strong and loyal customer shall never leave a side of his chosen brand due to firm faith, affection and integration of personality development with such brand allow him to stay with his side for a long span of time (Holland \& Menzel Baker 2001). Authors extensively defined brand loyalty as the combinations of six conditions that are based on intentions, attitude and belief system of consumers which are biased non-random, behavioural response that includes purchase, expression that are expressed over time, by some decision-making unit, out of different options available in the market, psychological decision making and evaluative process. Therefore, the potential impact of brand loyalty is at large scale to live up their prospects by satisfying brand aptitudes with their target audience leading to the following hypothesis:

$\mathrm{H}_{1}$ Corporate association positively and significantly impact on brand loyalty.

\section{BRAND LOYALTY AND SYMBOLIC BENEFITS}

Symbolic benefits are solely related to extrinsic values about non-product features and add values in terms of additive brand meaning that allows a customer to develop an affiliation and sense of belonging with its chosen product (Anisimova 2007). Factors such as sincerity, trust, excitement, competence, increase the personality of the brand through certain symbolic functions that increase overall interactions among both parties thus results in increased brand loyalty (Tran et al. 2013). Moreover, benefits the chosen brand shall incorporate for their customer will be a competitive advantage to develop trust among their target audience. This trust will allow visiting their outlet again and again with increased loyalty. The phenomena not only increase a strong bond (Aaker 1996) but it also allows a consumer to express his own personality through certain parameters and chosen indicators (Bian \& Moutinho 2011). Such factors will enhance the confidence level of both organization and customer for their brand selection and social status (Hoyer \& Stokburger-Sauer 2012). Thus, creating a positive impact on brand loyalty symbolic benefits contributes a vital role to enhance the utility and social status of the product thus encouraging the customer to pay the premium price against the chosen product leading to the following hypothesis:

$\mathrm{H}_{2} \quad$ Symbolic benefits positively and significantly impact on brand loyalty.

\section{BRAND LOYALTY AND FUNCTIONAL BENEFITS}

Functional benefits are solely concerned with intrinsic values driven by a brand towards customers (ErenErdogmus, Cobanoglu \& Turan 2015). As evidenced in the literature (Sweeney \& Soutar 2001) economic slump has slow down the consumer spending and increase monetary stress that brings down the revenues and margins of many firms across various geographical and different segments among luxury brands (Koritos, Koronios \& Stathakopoulos 2014). In other words, this economic slump has changed the perception and spending patterns of 
many consumers who are now more likely to focus on price than the quality of the chosen product. They consider the factual benefits they are seeking against the price they are actually playing against the product (Quelch \& Jocz 2009). So in this scenario, consumers are actually seeking the best deal (Koritos et al., 2014). The functional benefit is acting as the most important switching barrier in various categories of products (Lamey et al. 2007).

Functional benefits impacts on satisfaction with significant impact on behavioural factors such as creating positive vibe through greater quality results in high acceptability and committed relationship between the organization and consumer (Roos, Edvardsson \& Gustafsson 2004). Functional benefits stimulate the overall commitment of the company rather than focusing on individual gain hence driving the relationship towards overall committed driven profit margins (Hennig-Thurau, Gwinner \& Gremler 2002). Several findings have provided researches for functional benefits that solely includes monetary benefits and strategic gains obtained from the successful launch of the product in the market (Hastings 2003). Therefore, it can be hypothesized that:

$\mathrm{H}_{3}$ Functional benefits positively and significantly impact on brand loyalty.

\section{CUSTOMER INVOLVEMENT AND BRAND LOYALTY}

Sheth and Sharma (1997) extended the body of knowledge through specific relationship factors that include mutual adaptation, mutual trust, a mutual commitment that impacts a strong impact on the mutual relationship from both parties and contributes a lot towards customer involvement. Walter et al. (2003) illustrates that trust is an important factor for developing customer engagement and this will only be possible through clear price and premium quality at the initial stage to attract a maximum audience from the market (Scupola \& Nicolajsen 2013). Customers are nowadays an important consideration for every brand to work upon. Concept customer orientation was an important addition for successful market share among competitors. Luxury fashion branding is a concept of niche which attracts a very limited class of audience. This class of audience is very conscious against its preferences. So, the brands must endorse the feedback they gathered from their customers and incorporate to design such products which ultimately meet the expectations of the target audience. This shall exert a direct impact to enhance loyalty for the chosen brand. Different multinationals can avail such opportunity by offering differentiated services with reduced costs through user facility education shall enable a firm to grow its operations at large scale. More the degree of involvement is more is the likelihood of premium purchase. So, it can be hypothesized that:

$\mathrm{H}_{4}$ Customer involvement positively and significantly impact on brand loyalty.

\section{CUSTOMER RELATIONSHIP PRONENESS AND BRAND LOYALTY}

Relationship proneness makes customers looking for a close relationship, not for a short time contact. The significance of this feature is a proof for the investigation of loyalty, an individual who is not prone to involve in a relationship with a supplier has less prospect to become a loyal customer. Customer Relationship management serves as a potential medium for the development of a strong relationship with chosen customers. Moreover, this evaluation is a positive source of interaction between two parties which enhance the level of trust through closed and customized dealing between both parties. Relationship-prone customers are proved as a more loyal and higher tendency to stay in a relationship with the brand. Relationship prone to customers how more resistance to change. These types of customers cultivate a higher degree of trust and commitment which in-turns develop a brand (Carroll \& Ahuvia 2006). Firms want to attract and retain the relationship customers for higher profits as well. Researchers have investigated CRP as one feature which influences the loyalty that firms struggle to attain (Loureiro, Ruediger \& Demetris 2012). The significance of CRP for the study of BL is clear if firms are failed to prone customer relationships then, it becomes tough, to obtain BL. So, it can be hypothesized, that:

$\mathrm{H}_{5}$ Customer relationship proneness positively and significantly impact on brand loyalty.

\section{EMOTIONAL ATTACHMENT AND BRAND LOYALTY}

Brand loyalty depicts consumer dedication to keeping in touch with a specific brand (Morgan-Thomas \& Veloutsou 2013). Being emotionally attached reflects an association of that individual with a certain product and shows an enthusiasm towards that product (Albert \& Merunka 2013). Customers emotional affiliation is evidenced by three major strengths that are feeling of warmth, self- association with a certain brand and incorporating customers self-associations (Albert \& Merunka 2013). According to the literature it is necessitated for a situation having an increased level of emotional attachment is accountable for developing emotional trust in the brand. With the passage of time and increased commitment of a relationship, consumers tend to be more emotionally attached with such brand and are keen to have close attachment because the availability of such products provides a feeling 
of comfort, satisfaction, excitement, sophistication, and security (Hedrick, Beverland \& Minahan 2007). It can be hypothesized based on above-mentioned argumentation that:

$\mathrm{H}_{6} \quad$ Emotional attachment positively and significantly impacts on brand loyalty.

\section{THE MEDIATING ROLE OF EMOTIONAL ATTACHMENT BETWEEN THE CORPORATE ASSOCIATION AND BRAND LOYALTY}

There comes point in the life cycle of relationship where customers tend to look at the company as their firm partners and they shall develop trust and consistency for long term relationship(Jo Hatch \& Schultz 2003). This kind of action is mandatory from both parties to develop emotional attachment with a certain brand and on the other hand, a trustworthy and reliable partner shall always look for their customers and satisfy their needs and wants. This kind of action shall create an emotional response and allow different behavioural components to pursue positive emotions for high loyalty with a particular brand (Thomson, MacInnis \& Park 2005). Therefore, we can discuss that corporate exerts a greater responsibility towards their customers and whenever that positive belonging will create among their customer it will lead towards emotional attachment with specific brand endorsing high brand loyalty. Therefore, it can be hypothesized that:

$\mathrm{H}_{7}$ Emotional attachment will mediate the relationship between corporate association and brand loyalty.

\section{EMOTIONAL ATTACHMENT BETWEEN CORPORATE BENEFITS AND BRAND LOYALTY}

The customer whenever shall purchase any brand will develop psychological contact in terms of trust and high commitment and this bond shall allow their customers to develop highly functional utility with the same brand through high quality and other features that shall restrict customer to switch for any other options. So, based on the above discussion following is to be hypothesized:

$\mathrm{H}_{8} \quad$ Emotional attachment mediates a relationship between functional benefits and brand loyalty.

Psychological association with certain brand shall enhance consistency and high commitment with Chosen brand (Fournier 1998). Furthermore, customers are core components for value addition and maintaining an association with their brands. With these phenomena is primarily concerned with their psyche (Morgan \& Hunt 1994). Symbolic benefits are aligned with an emotional dilemma which is created by the brand to develop a distinguished personality in the market segment with the aim to have a higher level of loyalty.

$\mathrm{H}_{9}$ Emotional attachment plays a mediating role between the relationship of symbolic benefit and brand loyalty.

\section{CUSTOMERS INVOLVEMENT AND BRAND LOYALTY AND EMOTIONAL ATTACHMENT}

Customer involvement tends to create emotional attachment in a unique and distinctive way, especially when firms decide to introduce new services (Malär et al. 2012). Different ways of contribution decide an intensity of emotional attachment for different purchase cycles with customers to show high brand loyalty through high involvement and purchase processes. Along these lines, it would be a noteworthy preferred standpoint for the firms if somebody realized what the customers truly require. With the assistance of previous knowledge about CI, the firm can make a reasonable technique for building up the concepts (Hess, Fuller \& Mathew 2003). The organizations can utilize the customers in this procedure, not just to create new ideas for product/services but it can also be useful for getting a soft corner in the customer mind for long haul relationship and hold BL. One of the fundamental purposes behind involving customers is to get hold of information about the user's undeveloped requirements for achieving its feelings (Malär et al. 2012).

$\mathrm{H}_{10}$ Emotional attachment plays a mediating role in the relationship between customer involvement and brand loyalty.

\section{CUSTOMER RELATIONSHIP PRONENESS, BRAND LOYALTY, AND EMOTIONAL ATTACHMENT}

Reichheld, Teal and Smith (1996) discussed very prominently in his literature that customer can be emotionally attached through some supportive ends and these may include brand love, affection created from the brand, connection to stay loyal and develop trust among their target audience shall pursue a long-term relationship. Different characteristics take place but one of them is quite obvious and it can be explained as more the nature of 
emotional stability is in the mind of the customer, the more is the chances for him to develop loyalty and stay for a long span of time (Reichheld et al. 1996). Emotional attachment can better predict different purchase shares of the brand, actual brand purchases, and brand attitude developed (Park et al. 2010).

$\mathrm{H}_{11}$ Emotional Attachment mediates a relationship between customer relationship proneness and brand loyalty.

\section{CONCEPTUAL FRAMEWORK}

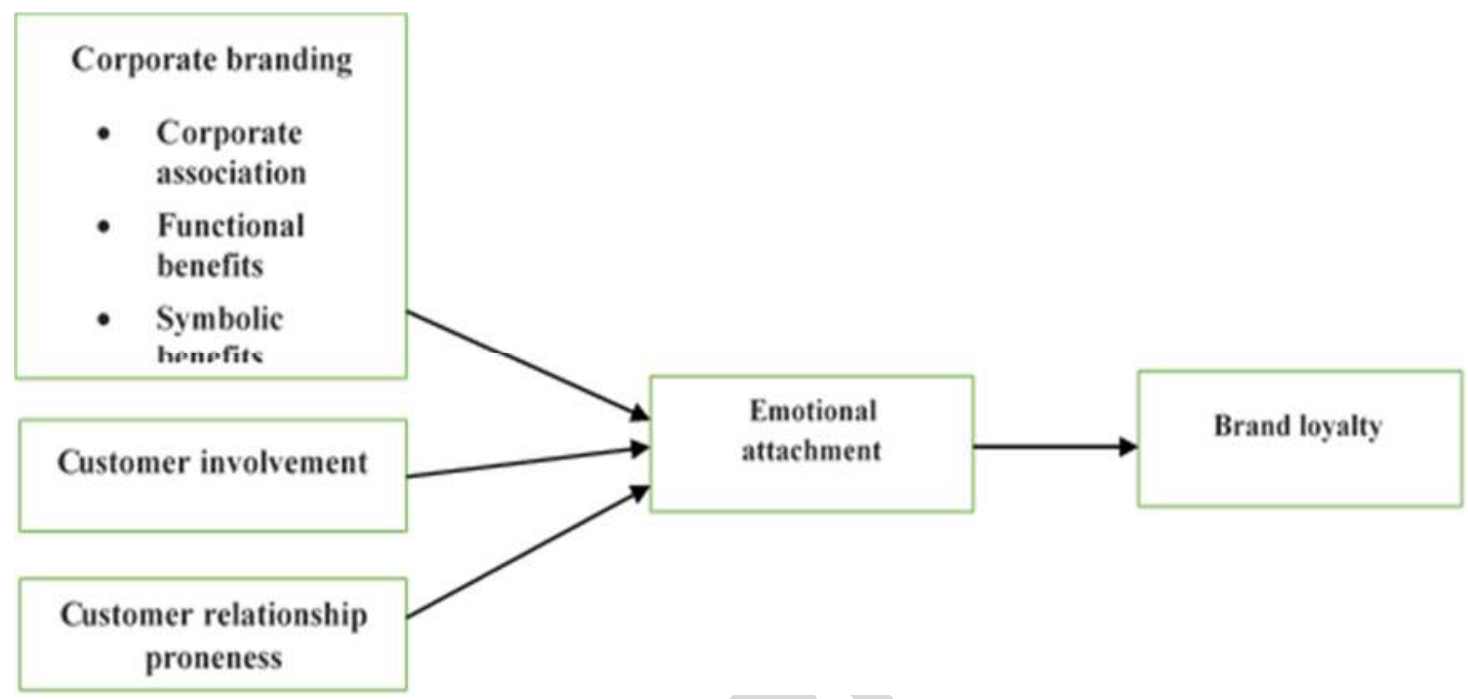

\section{METHODOLOGY AND ANALYSIS}

This section deals with the choice of research strategy, research approach, its design, a sample was drawn from the chosen population and different techniques used to perform certain actions for this research study. Following the stance of positivism, this research study is declined on the phenomena that reality is stand alone and is independent of the actions of social actors thus quantitative approach was used to have rational outcome based on law-like generalizations. Based on the justification of chosen theory the research study was evidenced to follow deductive approach with the aim to follow a cross-sectional design which explains the notion that data was collected at one point of time and from multiple respondents. Furthermore, the unit of analysis for this research study was respondents of five mega malls of twin cities of Pakistan.

A total of 450 questionnaires were distributed among chosen Mega Malls of Rawalpindi and Islamabad out of which 315 potential responses were collected drawn out of which 60 responses were collected from Centrum, 55 from Mid-way, 70 from Aashiana, 80 from Centaurus and 50 potential responses from Safa Gold Mall Islamabad following non-probability approach through convenience sampling technique. Data were collected from primary data sources through adapted scales cited from (Chevalier \& Mazzalovo 2008; Okonkwo, 2007)for measuring Corporate Benefits. Customer Involvement was adapted from (Hess et al. 2003). Moreover, Customer Relationship Proneness was adapted from (Bloemer et al. 2003) and Emotional Attachment was measured through adapted items cited from (Thomson et al. 2005). Brand Loyalty was measured through 4 items adapted from (Carroll \& Ahuvia 2006). A total of 29 items were designed through a five-point Likert scale to seek valuable responses for this research study.

\section{RESULTS}

Demographics for this research study were observed to be beneficial for this research study as they highlighted several distributions of classes and their exact range of participation towards this research study. A total of 111 male respondents with a percentage of $35 \%$ and 204 females $(65 \%)$ were observed during this research study who have contributed to the valuable outcome. The majority number of respondents was observed to have a bachelor's degree that clearly aligned with their age limits recorded for this research study. Cronbach alpha values for given research study were proved to be favourable in the light of evidence from (Gliem \& Gliem 2003) that constructs having alpha value 0.7 and 0.8 (corporate association .79, functional benefits .74, symbolic benefits .76, customer 
involvement .75 , customer relationship proneness .78 , emotional attachment .85 and brand loyalty .85$)$ is considered to be an excellent outcome.

TABLE 1. Correlation analysis

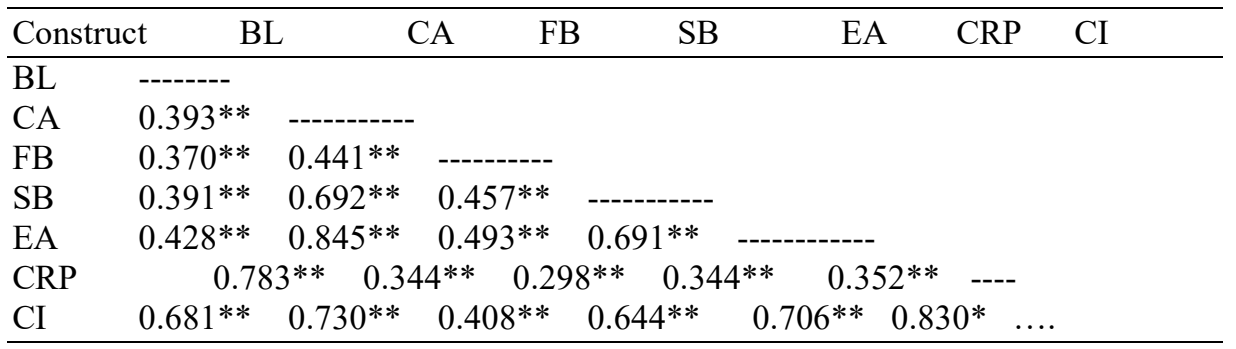

$\mathrm{N}=315, * * * 1 \%, * * 5 \%, * 10 \%$ (Corporate Association=CA, Functional Benefits $=$ FB, Symbolic Benefits $=$ SYB, Customer involvement $=$ CI, Customer relationship Proneness $=\mathrm{CRP}$, Emotional Attachment= EA, Brand Loyalty= BL).

The results are observed to have high association among chosen relationships that clearly portray a strong connection between developed relationships for both Independent, dependent and mediating variables. Associations that are observed to be more than 0.5 falls in the category of string associations between chosen constructs and the table shows every significant relationship having a positive value of more than 0.50 .

Once a high correlation among certainly chosen constructs is being observed is an indication of bias outcomes for the chosen research so the study tends to check whether the case multicollinearity exists or not through variance inflation factor and tolerance values. This test brings forth an indication of whether the relationship among different predictors is linear in a specific case. The value of 10 indicates a positive outcome and the table shows a value of 7.5 VIF with tolerance value of .124 against high correlation between CI and CRP which is .862 that can be safely concluded in the light of evidence from (Myers \& applications 1990) that multicollinearity is not an issue for the chosen framework.

TABLE 2. Mediation analysis

\begin{tabular}{|c|c|c|c|c|c|c|c|c|}
\hline & IV-DV & IV-MV & MV-DV & $\begin{array}{l}\text { Direct } \\
\text { Effect }\end{array}$ & $\begin{array}{l}\text { Indirect } \\
\text { Effect }\end{array}$ & $\begin{array}{l}\text { Total } \\
\text { Effect }\end{array}$ & LBCI & UBCI \\
\hline CA-EA-BL & $.196 * * *$ & $.778 * * *$ & $.421 * * *$ & .048 & $.148 * * *$ & $.196 * * *$ & .029 & .266 \\
\hline FB-EA-BL & $.226 * * *$ & $.135 * *$ & $.421 * * *$ & $.201 * * *$ & $.026 *$ & $.226 * * *$ & .006 & .055 \\
\hline SB-EA-BL & $.175 * * *$ & $.197 * * *$ & $421 * * *$ & $.138 * *$ & $.037 *$ & $.175 * * *$ & .010 & .013 \\
\hline CI-EA-BL & $.346 * * *$ & $.820 * * *$ & $.421 * * *$ & -.015 & $.361 * * *$ & $.346 * * *$ & .243 & .482 \\
\hline CRP-EA-BL & $.783 * * *$ & $.352 * * *$ & $.421 * * *$ & $.722 * * *$ & $.061 *$ & $.783 * * *$ & .034 & .093 \\
\hline
\end{tabular}

CA- Corporate Association; $\quad$ EA- Emotional Attachment; $\quad$ BL- Brand Loyalty; FB-Functional Benefits; SB-Symbolic Benefits; CI-Customer Involvement; $\quad$ CRP-Customer Relationship Proneness.

Table 2 consists of values showing the impacts of independent variables on dependent variables and mediating variable and the impact of the mediating variable on the dependent variable. Structural Equation Modelling (SEM) was run to analyze the data. AMOS was used for statistical analysis. Further, the direct and indirect effect along with the total effect of independent variables on the dependent variable via a mediating variable was measured by using Bootstrapping Method.

The directed relationship was observed to seek an impact of the first independent variable that was corporate association along with its three behavioural components on brand loyalty had provided a valuable outcome with significant F-statistics that shows a model fit having no match with a model having no predictor. CA was identified as the significant determinant of BL Thus, providing evidence to accept $\mathrm{H}_{1}$. Moreover, symbolic benefits were also proved to have a significant and positive effect on brand loyalty that clearly helps a researcher to accept $\mathrm{H}_{2}$. Functional benefits as observed from first two dimensions have contributed a positive input as well which shows a positive and significant impact through valuable and significant change that was observed through $\mathrm{B}$ statistic and significant value of F-statistic contributed to accept $\mathrm{H}_{3}$. The second indicator was observed to have a positive and significant association with brand loyalty as discussed in the above literature that customer involvement is an important indicator towards the development of brand loyalty and is proved through high association among chosen constructs. Furthermore, significant F-statistic brings about significant evidence for model fit and with significant $B$ statistic having a significance level of $p=.0000$ clearly shows the results are supporting the drawn literature concluding to accept $\mathrm{H}_{4}$. Customer relationship proneness that is an important indicator that develops trust among customers have also shown positive and significant results through significant F-statistics and high association among both variables have accepted $\mathrm{H}_{5}$ for this research study. 
Emotional attachment during a direct relationship with dependent variable brand loyalty had contributed positive and significant outcome confirming the second assumption for regression proved to be evident through significant F-statistic which shows model fit for this research study and significant value of B statistics draw an acceptance for H6. Full mediation was observed for corporate association at an insignificant level whereas partial mediation was observed for symbolic and functional benefits. Therefore, significant values for beta and drop in values for predictors with significant outcomes accept $\mathrm{H}_{7}, \mathrm{H}_{8}$, and $\mathrm{H}_{9}$ for this research study. Moreover, customer involvement stands insignificant in the presence of mediator that provide evidence of full mediation for this research study hence $\mathrm{H}_{10}$ is accepted whereas customer relationship proneness analysis showed a partial mediation as the value of beta dropped but remained to stand significant which accepts the $\mathrm{H}_{11}$ hypothesis with partial mediation. All the hypotheses including the hypotheses of mediation proved significant and true.

\section{DISCUSSION}

The study had highlighted many positive insights that proved to be beneficial from theoretical and practical point of view. Stated objectives and problem statement were successfully addressed through the positive outcome of certain indicators that safely concluded a significant impact of chosen variables on dependent variables. The findings explain that the values (symbolic and functional benefits) have limited effect on emotional attachment and brand loyalty as compared to other values. So, the previous studies who have claimed that symbolic and functional benefits help the customers to be a part of upper-class social group, is not fully set in Pakistani context. The finding shows that these values might be only explain a little part as antecedents of emotional attachment. The results further explain that, $\mathrm{CA}$ is crucial factor in driving emotional attachment. Therefore, it is important for the firms to develop a favourable association with customers. Favourable association can be developed through celebrity endorsement and inspiring the shopping experience (Theng So et al. 2013).

However, other values like CRP and CI have major contribution to drive the emotional attachment. These findings explain that the customers want to boost their experience through their involvement in the LFB. The involvement can be in terms of designing, co-production. Specifically, the findings explain that firms can nurture the loyalty of the customers through investing on customers involvement. Customer involvement is something that brings the customers closer to the firms. Many industries like healthcare, education, automotive, online shopping stores are using the customer involvement as strategy to boost their emotional attachment towards brand loyalty.

Unexpectedly, values of CB and CI were found to be low impacted on brand loyalty as compared to CRP. Possible explanation for this relationship can be brand loyalty explain about the long-term relationship. The firms who develop strong relationship with the customers can drive long-term brand loyalty. An alternative explanation could be that these finding only relate to the specific sample from whom we have collected the data. So, might be the sample group pays more attention to relationship than other values. The mediation role emotional attachment was found significant for all the proposed relationship.

\section{CONCLUSION}

In the light of evidence and analysis done on chosen constructs depicts clearly the impact on brand loyalty. Emotional attachment was observed as an important indicator towards both brand loyalty and mediation between independent and dependent variables. This research study was beneficial for both industrial and research point of view that clearly exerts an impact on brand loyalty through chosen predictors. Customer relationship proneness was observed to be an important indicator of the establishment of trust and commitment for several firms that shall enable an organization to launch a successful product and make customers stick with it. Results have shown exceptional benchmarks for highest associations among chosen variables with customer involvement, customer relationship proneness and emotional attachment being observed as highly associated with the dependent variable. This observation shows the importance of customers that must be involved during development stages through market feedback which serves as a potential advantage for luxury brands to charge premium prices. A gap of the study was fulfilled through the incorporation of the partially/fully mediated role of emotional attachment that has contributed fruitful insights towards the development of trust and commitment and loyalty towards luxury fashion branding. Emotional attachment was observed to be an important indicator to develop trust and commitment among customers through chosen predictors for this research study. The current study only captured one area i.e. fashion industry of Pakistan. So, it can be negative aspects that findings and results may not be the findings and results of another corporate area. Finally, future studies should be conducted using a large sample size and different sectors from all over Pakistan in order to get the best results. 


\section{REFERENCES}

Aaker, D. A. 1996. Measuring brand equity across products and markets. California Management Review 38(3): 102.-120.

Abratt, R. \& Kleyn, N. 2012. Corporate identity, corporate branding and corporate reputations: Reconciliation and integration. European Journal of Marketing 46(7/8): 1048-1063.

Albert, N. \& Merunka, D. 2013. The role of brand love in consumer-brand relationships. Journal of Consumer Marketing 30(3): 258-266.

Anisimova, T.A. 2007. The effects of corporate brand attributes on attitudinal and behavioural consumer loyalty. Journal of Consumer Marketing 24(7): 395-405.

Arora, A.P. 2017. Buying behaviour of consumers towards luxury fashion brands. Global Journal of Enterprise Information System 9(2): 123-126.

Beneke, J. \& Zimmerman, N. 2014. Beyond private label panache: The effect of store image and perceived price on brand prestige. Journal of Consumer Marketing 31(4): 301-311.

Bian, X. \& Moutinho, L. 2011. The role of brand image, product involvement, and knowledge in explaining consumer purchase behaviour of counterfeits: Direct and indirect effects. European Journal of Marketing 45(1/2): 191-216.

Bloemer, J., Odekerken-Schröder, G., Kestens, L.J.J.o.R. \& Services, C. 2003. The impact of need for social affiliation and consumer relationship proneness on behavioural intentions: An empirical study in a hairdresser's context. Journal of Retailing and Consumer Services 10(4): 231-240.

Brown, T.J. \& Dacin, P.A. 1997. The company and the product: Corporate associations and consumer product responses. The Journal of Marketing 61(1): 68-84.

Carroll, B.A. \& Ahuvia, A.C. 2006. Some antecedents and outcomes of brand love. Marketing Letters 17(2): 7989.

Chevalier, M. \& Mazzalovo, G. 2008. Luxury Brand Management: A World of Privilege. Singapore: John Wiley $\&$ Sons.

Eom, H.J. \& Seock, Y.-K. 2017. Purchase intention toward luxury fashion brands from the social comparison perspective. In Marketing at the Confluence between Entertainment and Analytics, 1277-1280. London: Springer.

Eren-Erdogmus, I., Cobanoglu, E. \& Budeyri-Turan, I. 2015. Exploring dimensions of brand personality for Generation Y in the apparel market: The case of Turkey. Journal of Global Fashion Marketing 6(2): 150161.

Esmaeilpour, F. 2015. The role of functional and symbolic brand associations on brand loyalty: A study on luxury brands. Journal of Fashion Marketing and Management 19(4): 467-484.

Fionda, A.M. \& Moore, C.M. 2009. The anatomy of the luxury fashion brand. Journal of Brand Management 16(5-6): 347-363.

Fournier, S. 1998. Consumers and their brands: Developing relationship theory in consumer research. Journal of Consumer Research 24(4): 343-373.

Gliem, J.A. \& Gliem, R.R. 2003. Calculating, interpreting, and reporting Cronbach's alpha reliability coefficient for Likert-type scales. Midwest Research to Practice Conference in Adult, Continuing, and Community Education, Columbus, 82-88.

Harris, F. \& De Chernatony, L. 2001. Corporate branding and corporate brand performance. European Journal of Marketing 35(3/4): 441-456.

Hastings, G. 2003. Relational paradigms in social marketing. Journal of Macromarketing 23(1): 6-15.

Hedrick, N., Beverland, M. \& Minahan, S. 2007. An exploration of relational customers' response to service failure. Journal of Services Marketing 21(1): 64-72.

Hennig-Thurau, T., Gwinner, K.P. \& Gremler, D.D. 2002. Understanding relationship marketing outcomes: An integration of relational benefits and relationship quality. Journal of Service Research 4(3): 230-247.

Hess, T.J., Fuller, M.A. \& Mathew, J.J.S.P. 2003. Gender and personality in media rich interfaces: Do birds of a feather flock together? Proceedings of the Second Annual Workshop on HCI Research in MIS, Seattle, WA, December 12-13.

Holland, J. \& Menzel Baker, S. 2001. Customer participation in creating site brand loyalty. Journal of Interactive Marketing 15(4): 34-45.

Hoyer, W.D. \& Stokburger-Sauer, N.E. 2012. The role of aesthetic taste in consumer behavior. Journal of the Academy of Marketing Science 40(1): 167-180.

Jo Hatch, M. \& Schultz, M. 2003. Bringing the corporation into corporate branding. European Journal of Marketing 37(7/8): 1041-1064.

Kinley, T.R., Josiam, B.M. \& Lockett, F. 2010. Shopping behavior and the involvement construct. Journal of Fashion Marketing and Management: An International Journal 14(4): 562-575. 
Ko, E. \& Megehee, C. M. 2012. Fashion marketing of luxury brands: Recent research issues and contributions. Journal of Business Research 65(10): 1395-1398.

Koritos, C., Koronios, K. \& Stathakopoulos, V. 2014. Functional vs relational benefits: What matters most in affinity marketing? Journal of Services Marketing 28(4): 265-275.

La Rocca, A. 2011. Interaction and actors 'identities in business relationships. Università della Svizzera Italiana,

Lamey, L., Deleersnyder, B., Dekimpe, M.G. \& Steenkamp, J.-B. E. 2007. How business cycles contribute to private-label success: Evidence from the United States and Europe. Journal of Marketing 71(1): 1-15.

Loureiro, S.M.C., Ruediger, K.H. \& Demetris, V. 2012. Brand emotional connection and loyalty. Journal of Brand Management 20(1): 13-27.

Malär, L., Nyffenegger, B., Krohmer, H., \& Hoyer, W. D. 2012. Implementing an intended brand personality: A dyadic perspective. Journal of the Academy of Marketing Science 40(5): 728-744.

Morgan-Thomas, A. \& Veloutsou, C. 2013. Beyond technology acceptance: Brand relationships and online brand experience. Journal of Business Research 66(1): 21-27.

Morgan, R.M. \& Hunt, S.D. 1994. The commitment-trust theory of relationship marketing. The Journal of Marketing 58: 20-38.

Myers, R.J.C. \& applications, m.r.w. 1990. Detecting and combating multicollinearity. In Classical and Modern Regression with Applications, edited by Myers, R.H., 368-423. North Scituate, MA:Duxbury Press.

Ngobo, P.V. 2011. What drives household choice of organic products in grocery stores? Journal of Retailing 87(1): 90-100.

O'Cass, A. \& Ngo, L.V. 2011. Examining the firm's value creation process: A managerial perspective of the firm's value offering strategy and performance. British Journal of Management 22(4): 646-671.

Okonkwo, U. 2007. What's in a name? The history of luxury fashion branding. In Luxury Fashion Branding, 1358. London: Palgrave Macmillan.

Park-Poaps, H. \& Kang, J. 2018. An experiment on non-luxury fashion counterfeit purchase: The effects of brand reputation, fashion attributes, and attitudes toward counterfeiting. Journal of Brand Management 25(2): 185196.

Park, W. 2010. Brand attachment and brand attitude strength: Conceptual and empirical differentiation of two critical brand equity drivers. Journal of Marketing 74(6): 1-17.

Quelch, A. \& Jocz, K.E. 2009. Keeping a keen eye on consumer behaviour. Financial Times.

Reichheld, F.F., Teal, T. \& Smith, D.K. 1996. The Loyalty Effect (Vol. 1). Boston, MA: Harvard Business School Press.

Reisenwitz, T.H. \& Gupta, S. 2011. Assessing the effectiveness of a product warranty in a health-care setting. Journal of Medical Marketing 11(2): 109-118.

Romaniuk, J. \& Gaillard, E. 2007. The relationship between unique brand associations, brand usage and brand performance: Analysis across eight categories. Journal of Marketing Management 23(3-4): 267-284.

Roos, I., Edvardsson, B. \& Gustafsson, A. 2004. Customer switching patterns in competitive and noncompetitive service industries. Journal of Service Research 6(3): 256-271.

Ryan, F. 2009. Technology will boost consumers' global power. Caribbean Business 37(9): 38-40.

Sallam, M.A. 2016. The impact of brand image and corporate branding on consumer's choice: The role of brand equity. International Journal of Marketing Studies 8(1): 98-106.

Scupola, A. \& Nicolajsen, H.W. 2013. Using social media for service innovations: Challenges and pitfalls. International Journal of E-Business Research (IJEBR) 9(3): 27-37.

Sheth, J.N. \& Sharma, A. 1997. Supplier relationships: Emerging issues and challenges. Industrial Marketing Management 26(2): 91-100.

Souiden, N., Kassim, N.M. \& Hong, H.-J. 2006. The effect of corporate branding dimensions on consumers' product evaluation: A cross-cultural analysis. European Journal of Marketing 40(7/8): 825-845.

Sweeney, J.C. \& Soutar, G.N. 2001. Consumer perceived value: The development of a multiple item scale. Journal of Retailing 77(2): 203-220.

Theng So, J., Grant Parsons, A. \& Yap, S.-F. 2013. Corporate branding, emotional attachment and brand loyalty: The case of luxury fashion branding. Journal of Fashion Marketing and Management: An International Journal 17(4): 403-423.

Thomson, M., MacInnis, D.J. \& Whan Park, C. 2005. The ties that bind: Measuring the strength of consumers' emotional attachments to brands. Journal of Consumer Psychology 15(1): 77-91.

Tran, X., Dauchez, C. \& Szemik, A.-M. 2013. Hotel brand personality and brand quality. Journal of Vacation Marketing 19(4): 329-341.

Walter, A., Müller, T.A., Helfert, G. \& Ritter, T. 2003. Functions of industrial supplier relationships and their impact on relationship quality. Industrial Marketing Management 32(2): 159-169.

Whan Park, C., MacInnis, D.J., Priester, J., Eisingerich, A.B. \& Iacobucci, D.J.J.o.m. 2010. Brand attachment and brand attitude strength: Conceptual and empirical differentiation of two critical brand equity drivers. Journal of Marketing 74(6): 1-17. 
Yu Xie, H. \& Boggs, D. J. 2006. Corporate branding versus product branding in emerging markets: A conceptual framework. Marketing Intelligence \& Planning 24(4): 347-364.

Muhammad Amin (corresponding author) Management and Humanities Department Universiti Teknologi PETRONAS

31750 Seri Iskander, Perak, MALAYSIA.

E-Mail:amin.wraich@gmail.com

Zulkipli Ghazali

Management and Humanities Department Universiti Teknologi PETRONAS

31750 Seri Iskander, Perak, MALAYSIA.

E-Mail: zulkipli_g@utp.edu.my

Amir Gulzar

Department of Management Sciences

Foundation University

46000 Islamabad, PAKISTAN.

E-Mail: amirgulzar@hotmail.com 